\author{
Piotr Szukalski \\ Instytut Socjologii \\ Uniwersytet Łódzki \\ pies@uni.lodz.pl
}

\title{
LUDZIE BARDZO STARZY - NIEWIDOCZNA GRUPA DOCELOWA POLITYKI SPOŁECZNEJ?
}

\section{WPROWADZENIE}

Długowieczność była zawsze stanem pożądanym, a w ciągu ostatnich dekad wyraźnie zwiększyła się grupa osób osiągających bardzo zaawansowany wiek. Pod wieloma względami społeczeństwo i jego instytucje - organizacje, sposoby myślenia i działania - nie są jednak przygotowane na wzrost liczby osób bardzo starych. Terminem tym w polskich realiach najczęściej określa się osoby w wieku 80 lat i więcej, choć w literaturze gerontologicznej krajów bardziej zaawansowanych w procesie starzenia się ludności wiek ten jest zazwyczaj definiowany jako przynajmniej 85 lat, zaś przynależące do niego jednostki noszą miano najstarszych starych ${ }^{1}$. Niezależnie

1 Stosowane pojęcia w dużym stopniu odzwierciedlają rozwój sposobu myślenia o interesującej nas kategorii osób. Na przykład, wspomniana nazwa „najstarsi starzy” ( $\mathrm{z}$ ang. the oldest old) pojawiła się w amerykańskiej gerontologii wypełniając dwa zadania: po pierwsze, zmniejszając „odium uciążliwości” przypisane młodszym seniorom (od początku lat 70 . stosowano bowiem podział seniorów na „,młodych starych" - 65-74 lata - i ,starych starych" - 75 lat i więcej, mający oddzielić w pełni samodzielnych seniorów od tych potrzebujących wsparcia w postaci usług opiekuńczo-pielęgnacyjnych, co z kolei prowadziło do traktowania wszystkich osób w wieku 75 lat i więcej jako homogeniczną grupę beneficjentów), po drugie zaś zwrócić uwagę na jednostki najstarsze, zgłaszające największe zapotrzebowanie na usługi wspomagające o specyficznym charakterze.

Inna stosowana nazwa dla analizowanej w niniejszym tekście grupy to osoby w czwartym wieku, tj. osoby, które są niesamodzielne zarówno ekonomicznie (utrzymywanie się ze świadczeń społecznych, przede wszystkim emerytur), jak i funkcjonalnie (niemożność samodzielnego wykonywania wszystkich czynności dnia codziennego). Zaznaczyć należy, iż w tym ostatnim przypadku, mimo odwoływania się do faktycznej sprawności i samodzielności, również stosuje się uznaniowe granice. W momencie pojawiania się tego terminu pod koniec lat 60 . we Francji granica ta była tożsama $\mathrm{z}$ wiekiem określanym w niniejszym opracowaniu za sędziwy, tj. $\mathrm{z}$ wiekiem 80 lat.

W rzeczywistości wszystkie te granice określają arbitralnie wiek, od którego zdecydowana większość osób jest niesamodzielna lub niedołężna, używając terminu stosowanego w początkach konstruowania zabezpieczenia społecznego na starość. Występujące pomiędzy państwami różnice odnośnie do 
od używanych nazw, grupę osób najstarszych wyodrębnia się z uwagi na ich specyficzne potrzeby wynikające $z$ narastającej niesamodzielności oraz na duże natężenie owych potrzeb. Niższa - w porównaniu z szeregiem państw najwyżej rozwiniętych - granica wieku używana w Polsce do odróżnienia osób bardzo starych od innych seniorów wynika z gorszego stanu zdrowia, wcześniej pojawiających się symptomów niesamodzielności oraz wyższej umieralności.

Celem niniejszego opracowania jest wskazanie tych problemów lokalnej polityki społecznej, które wynikają ze specyficznych potrzeb opiekuńczo-pielęgnacyjnych subpopulacji osób bardzo starych, a zwłaszcza tych, które są w świetle prognoz demograficznych w pełni przewidywalne. Mimo powszechnej świadomości procesu starzenia się ludności Polski problemy osób osiągających bardzo zaawansowany wiek są zazwyczaj marginalizowane. Ma miejsce swoiste rozmycie odpowiedzialności za zaspokajanie potrzeb osób najstarszych wynikające $\mathrm{z}$ istnienia dwóch systemów pomocy (pomocy społecznej i służby ochrony zdrowia) i, po części, z panującego przekonania, iż zapewnienie usług opiekuńczo-pielęgnacyjnych nie jest zadaniem tylko jednej jednostki decyzyjno-organizacyjnej. Przekłada się to zapewne na marginalizowanie wyników prognoz demograficznych. Sprzyja temu też fakt, iż wielu lokalnych decydentów zna jedynie prognozy demograficzne odnoszące się do kraju ogółem, rzadko zdając sobie sprawę z dostępności danych i rezultatów prognoz na poziomie powiatów. $Z$ perspektywy powstawania rozbieżności pomiędzy zapotrzebowaniem na usługi a ich podażą jest to o tyle niekorzystne, iż osoby bardzo stare z definicji korzystają intensywnie $\mathrm{z}$ usług publicznych, a tymczasem decydenci odpowiedzialni za politykę społeczną na różnych szczeblach nie zdają się dostrzegać wzrostu liczby najstarszych Polaków.

Drugim celem opracowania jest wskazanie, jak niewielkie zmiany poziomu umieralności prowadzą w relatywnie krótkim okresie do znacznych zmian liczby osób dożywających zaawansowanej starości. Porównanie dwóch ostatnich prognoz Głównego Urzędu Statystycznego (GUS), to jest tej z 2008 i tej z 2014 roku, powinno bowiem być przestrogą przed tym, iż w wyniku szybszej od założonej redukcji natężenia zgonów populacja osób bardzo starych zwiększa się znacznie bardziej, niż wynikałoby z owych oficjalnych przewidywań.

stosowanych definicji wieku zaawansowanej starości odzwierciedlają różnice stanu zdrowia i odmienne tradycje określania niesamodzielności. Obecnie preferowane są opisowe kategorie pojęciowe, o jak najmniej wartościującym charakterze, co doprowadziło na przykład do zaniku terminu „sędziwy starzec", którego jeszcze pół wieku temu używał E. Rosset do określenia osób w wieku 80 lat i więcej. 


\section{ZMIANY LICZEBNOŚCI I STRUKTURY POPULACJI OSÓB BARDZO STARYCH}

Proces starzenia się ludności stał się już trwałym elementem współczesnej świadomości społecznej. Mniej znany jest proces tzw. podwójnego starzenia się ludności, według którego w społeczeństwach charakteryzujących się niską umieralnością wraz ze wzrostem odsetka osób starszych następuje jednocześnie zmiana struktury tej subpopulacji, polegająca na jeszcze szybszym wzroście liczby osób najstarszych ${ }^{2}$. Generalnie, z im starszą grupą mamy do czynienia, tym wyższe jest tempo przyrostu jej liczebności. Wynika to przede wszystkim z kumulowania się rezultatów obniżania się umieralności na wcześniejszych etapach życia, czemu przyjrzę się dokładniej w dalszej części niniejszego opracowania. W rezultacie grupa osób bardzo starych odznacza się we współczesnych, rozwiniętych społeczeństwach wysokim tempem wzrostu ilościowego. Ograniczając się do okresu po II wojnie światowej, zauważyć można w Polsce stały, znaczny wzrost liczby osób w wieku 80 lat i więcej (tablica 1), która w trakcie ostatnich 60 lat (1950-2012) wzrosła ośmiokrotnie, podczas gdy liczba ludności Polski zwiększyła się w tym okresie o 55\%, zaś liczba osób w wieku 65 lat i więcej o $316 \%$.

Starzenie się subpopulacji seniorów zachodzi także w ramach zbiorowości osób bardzo starych, aczkolwiek zdawać sobie należy sprawę, iż efekt kohortowy, polegający na opóźnionym wpływie zdarzeń na liczbę wydawanych kilkadziesiąt lat temu na świat dzieci, modyfikuje niekiedy znacząco liczbę jednostek w bardziej jednorodnych grupach wieku (rys. 1). Opóźnione oddziaływanie ,praw demograficznych wojny" sprawiało, iż zachowania demograficzne z okresu obu wojen światowych (czas rezygnowania z prokreacji lub odraczania tego typu decyzji) oraz z okresu powojennej kompensacji ukształtowały z kilkudziesięcioletnim opóźnieniem względną liczbę poszczególnych podgrup starszego wieku w sposób niezgodny z oczekiwaniami bazującymi jedynie na założeniu o jednokierunkowych, stałych zmianach. Na przykład, obserwowany na początku XXI wieku wzrost udziału grupy osób w wieku przynajmniej 90 lat wynikał z mniejszej liczebności osób młodszych, urodzonych w czasie I wojny światowej, gdy zaś wiek 85-89 lat zaczęły osiągać roczniki urodzone na początku lat 20., odsetek dziewięćdziesięciolatków powrócił do stanu wcześniejszego.

2 Zainteresowanych bardziej rozbudowanymi informacjami o demografii podwójnego starzenia się i specyficznych cechach populacji osób bardzo starych odsyłam do innych publikacji (Szukalski 2004, 2006, 2013a). 
Tablica 1 Liczba osób w wieku 80 lat i więcej w Polsce w latach 1950-2030 i dynamika jej zmian

Table 1. Number and dynamics of population aged 80 and more in Poland, 1950-2030

\begin{tabular}{|c|c|c|c|c|c|c|c|}
\hline \multirow{2}{*}{$\begin{array}{l}\text { Rok } \\
\text { Year }\end{array}$} & \multicolumn{7}{|c|}{ Wiek Age } \\
\hline & $65+$ & $80+$ & $80-84$ & $85-89$ & $90-94$ & $95-99$ & $100+$ \\
\hline \multicolumn{8}{|c|}{ W tysiącach in thousands } \\
\hline 1950 & 1318,2 & 180,3 & 117,1 & 45,7 & 12,5 & 4,7 & 0,3 \\
\hline 1960 & 1788,5 & 213,0 & 141,7 & 54,6 & 13,3 & 3,0 & 0,4 \\
\hline 1970 & 2736,3 & 334,7 & 228,0 & 82,7 & 20,2 & 3,6 & 0,3 \\
\hline 1978 & 4053,5 & 479,6 & 323,1 & 115,2 & 33,8 & 7,0 & 0,4 \\
\hline 1988 & 3757,1 & 739,9 & 484,8 & 196,5 & 47,0 & 10,1 & 1,6 \\
\hline 2002 & 4852,6 & 827,7 & 489,8 & 228,9 & 91,7 & 15,8 & 1,5 \\
\hline 2011 & 5230,1 & 1347,7 & 815,9 & 405,0 & 100,7 & 23,0 & 3,1 \\
\hline 2012 & 5487,7 & 1443,3 & 855,9 & 434,1 & 128,4 & 21,1 & 3,8 \\
\hline $2012 *$ & 5405,6 & 1405,9 & 830,0 & 422,3 & 129,3 & 21,1 & 3,2 \\
\hline $2020 *$ & 6953,6 & 1566,4 & 815,2 & 491,1 & 207,5 & 48,3 & 4,4 \\
\hline $2020 * *$ & 7193,6 & 1684,4 & 864,1 & 535,0 & 228,3 & 52,4 & 4,6 \\
\hline $2030^{*}$ & 8195,4 & 2005,2 & 1222,3 & 466,6 & 234,7 & 69,8 & 11,8 \\
\hline $2030 * *$ & 8646,5 & 2205,9 & 1315,1 & 515,1 & 273,8 & 86,4 & 15,4 \\
\hline \multicolumn{8}{|c|}{ Indeksy łańcuchowe chain indices } \\
\hline 1960 & 135,7 & 118,1 & 121,0 & 119,5 & 106,4 & 63,8 & 133,3 \\
\hline 1970 & 153,0 & 157,1 & 160,9 & 151,5 & 151,9 & 120,0 & 75,0 \\
\hline 1978 & 148,1 & 143,3 & 141,7 & 139,3 & 167,3 & 194,4 & 133,3 \\
\hline 1988 & 92,7 & 154,3 & 150,0 & 170,6 & 139,1 & 144,3 & 400,0 \\
\hline 2002 & 129,2 & 111,9 & 101,0 & 116,5 & 195,1 & 156,4 & 93,8 \\
\hline 2011 & 107,8 & 162,8 & 166,6 & 176,9 & 109,8 & 145,6 & 206,7 \\
\hline $2020 *$ & 133,0 & 116,2 & 99,9 & 121,3 & 206,1 & 210,0 & 141,9 \\
\hline $2020 * *$ & 137,5 & 125,0 & 105,9 & 132,1 & 226,8 & 228,0 & 147,5 \\
\hline $2030^{*}$ & 117,9 & 128,0 & 149,9 & 95,0 & 113,1 & 144,5 & 268,2 \\
\hline $2030 * *$ & 120,2 & 131,0 & 152,2 & 96,3 & 119,9 & 164,8 & 337,8 \\
\hline
\end{tabular}

* Wartości prognozy GUS z 2008 roku. ** Wartości prognozy GUS z 2014 roku.

** Results of the 2008 Central Statistical Office (CSO) forecast. ** Results of the 2014 CSO forecast.

Źródło: dane z Narodowych Spisów Powszechnych, GUS (2014a,c).

Source: data from population censuses, GUS (2014a,c). 
Rysunek 1. Rozkład populacji osób bardzo starych według wieku w latach 1950-2030

Figure 1. Distribution of the Polish oldest old by age group, 1950-2030

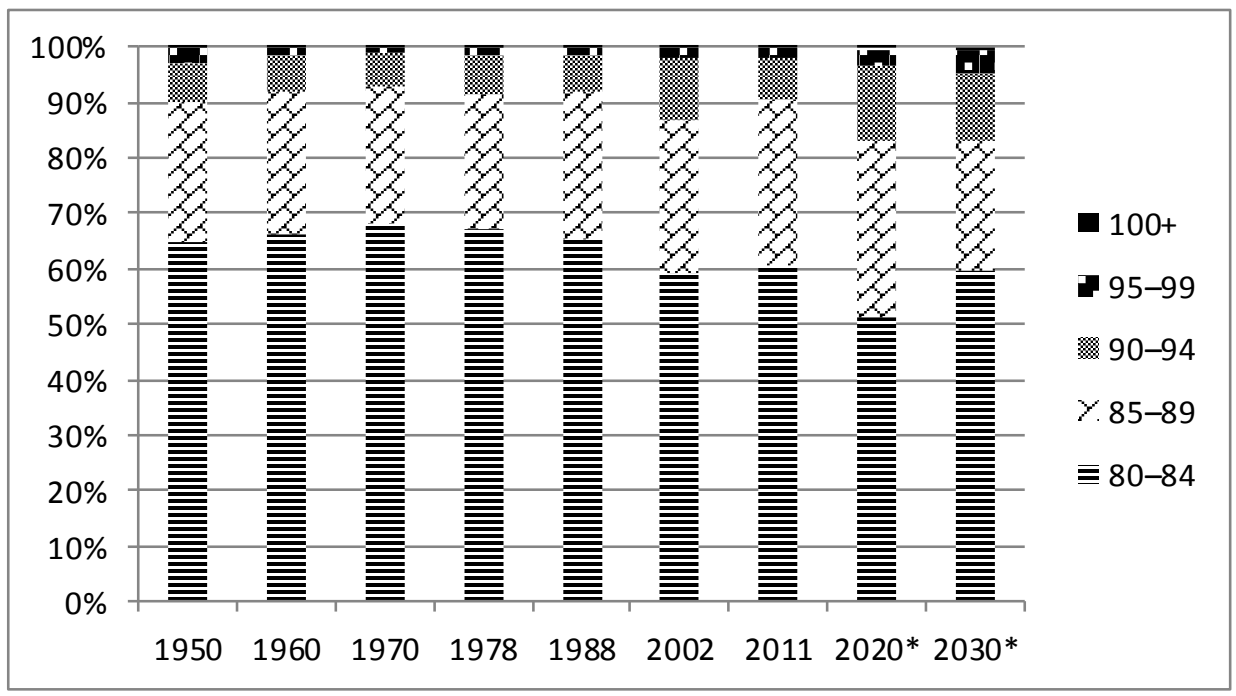

* Wartości prognozy GUS z 2008 roku.

* Results of the 2008 CSO forecast.

Źródło: dane Narodowych Spisów Powszechnych, GUS (2014a,c).

Source: data from population censuses, GUS (2014a,c).

W okresie powojennym zwiększała się nie tylko liczba osób bardzo starych, ale także ich frakcja wśród ludności ogółem, przybierając następujące wartości: 1950 - 0,7\%, $1960-0,8 \%, 1970-1,0 \%, 1978-1,5 \%, 1988-2,0 \%, 2011-3,6 \%, 2012$ $-3,7 \%$. W nadchodzących latach spodziewany jest dalszy, bardzo szybki wzrost liczby osób bardzo starych w Polsce, których liczba wzrośnie w ciągu kilkunastu lat o ponad $40 \%$, przy jednoczesnym szybszym wzroście liczebności podgrup o najstarszym wieku. Dziać się tak będzie zarówno w wyniku dalszego ograniczania umieralności, jak i - po roku 2025 - w wyniku osiągania wieku 80 lat i więcej przez liczne generacje urodzone $\mathrm{w}$ pierwszych powojennych latach, czyli tzw. okresie powojennego baby-boomu. W rezultacie nastąpi wzrost liczby osób w wieku 80 lat i więcej (tablica 1), który w połączeniu z prognozowanym spadkiem liczebności populacji Polski prowadzić będzie do zwiększania się udziału osób bardzo starych do $4,1 \%$ w 2020 roku i 5,5\% w 2030 roku według prognozy GUS z 2008 roku lub odpowiednio do 4,4\% i 5,9\% według prognozy z 2014 r.

Przedstawione wyżej prognozowane wielkości bezwzględne i względne zapewne w rzeczywistości będą wyższe. W ostatnich latach bowiem spadek umieralności był zdecydowanie wyższy, niż ten przyjęty w założeniach prognozy GUS 
z 2008 roku $^{3}$, co będzie oddziaływać na liczbę osób dożywających zaawansowanego wieku. Już w 2012 roku odnotowana liczba najstarszych Polaków była wyższa o 37 tys., czyli o 2,6\%, w stosunku do prognoz dla tego roku (tablica 1). W rezultacie rzeczywiste liczby osób bardzo starych będą za 10-20 lat nieco - o kilka lub kilkanaście procent - wyższe od tych wynikających z prognozy GUS z 2008 roku, przy czym różnica ta będzie tym większa, im starszego wieku będzie dotyczyć. Takie oczekiwania potwierdzają wyniki prognozy GUS z 2014 roku wskazujące na znacznie wyższą w przyszłości liczbę sędziwych starców od tej wynikającej z wcześniejszej prognozy (tablica 2).

Tablica 2. Liczba osób w wieku 80 lat i więcej w latach 2015-2035 według prognoz GUS z 2008 i 2014 roku, w tys.

Table 2. Number of people aged 80 and more in Poland in 2015-2035 according to the CSO forecasts from 2008 and 2014, in thousands

\begin{tabular}{|l|c|c|c|c|c|}
\hline $\begin{array}{c}\text { Prognoza z roku } \\
\text { Forecast from year }\end{array}$ & 2015 & 2020 & 2025 & 2030 & 2035 \\
\hline 2008 & 1488 & 1566 & 1537 & 2005 & 2574 \\
\hline 2014 & 1560 & 1684 & 1680 & 2206 & 2869 \\
\hline
\end{tabular}

Źródło: opracowanie własne na podstawie GUS (2009, 2014b).

Source:own elaboration based on GUS (2009, 2014b).

Według ostatniej prognozy, już w roku 2015 sędziwych starców będzie o ponad 70 tys. więcej, zaś w perspektywie następnego dwudziestolecia rozbieżność pomiędzy dwiema prognozami będzie narastać. Dla 2035 roku różnica ta wyniesie blisko 300 tys., co jednoznacznie wskazuje na skalę zmian wywołanych redukcją umieralności. Zaznaczyć należy, że również i prognoza GUS z 2014 roku nie bazuje na optymistycznych założeniach odnośnie do obniżania się umieralności, zakładając utrzymywanie się opóźnienia w stosunku do innych rozwiniętych, europejskich krajów w długim czasie ${ }^{4}$. Obniżanie się umieralności w tempie wyższym, niż to założone w powyższej prognozie, samoistnie przekładać się będzie na poziomie jednostkowym na wzrost prawdopodobieństwa dożycia bardzo zaawansowanego wieku, a na poziomie społecznym na wzrost liczby najstarszych Polaków.

3 Przykładowo, odnotowane w roku 2012, trwanie życia noworodka jest wyższe w przypadku mężczyzn od tego założonego zgodnie z prognozą GUS dla roku 2015, zaś w przypadku kobiet od wielkości przyjętej dla 2020 roku.

4 To mało optymistyczne założenie ,zderzyło” się od razu z rzeczywistością, w roku 2014 bowiem zmarło 372,2 tys. osób zamiast przewidywanych przez prognozę 384,1 tys. 


\section{CZYNNIKI WARUNKUJĄCE PODWÓJNE STARZENIE SIĘ LUDNOŚCI}

Pierwszym czynnikiem warunkującym wzrost liczby osób bardzo starych są zmiany liczby urodzeń w pierwszych dekadach XX wieku. Biorąc jednak pod uwagę zmienność owej liczby wynikającą z nakładania się trzech czynników - sekularnego spadku poziomu dzietności, dochodzenia do wieku prokreacji coraz liczniejszych generacji, wpływu kryzysów społecznych o charakterze politycznym (wojny światowe, wojna 1920 roku) i ekonomicznym (kryzys lat 1929-1933) - trudno jednoznacznie ocenić wpływ tej zmiennej na dotychczas zaobserwowane zmiany liczby najstarszych seniorów. Dodatkowo utrudnia to zadanie powojenna zmiana granic Polski.

Drugim czynnikiem zwiększającym liczebność populacji osób bardzo starych w długim okresie jest redukcja umieralności, w wyniku której rośnie prawdopodobieństwo dożycia do sędziwego wieku. Świadectwem wspomnianego procesu niech będą dane pochodzące z powojennych tablic trwania życia, wskazujące, ile osób spośród 100 tys. noworodków dożywałoby do zaawansowanego wieku w warunkach utrzymywania się umieralności z danego roku (tablica 3).

Tablica 3. Liczba osób dożywających wieku 80, 90 i 100 lat w Polsce w latach 1952-2013, według płci

Table 3. Number of persons surviving to age of 80, 90, 100 years in Poland, 1952-2013, by sex

\begin{tabular}{|c|c|c|c|c|c|c|}
\hline \multirow{2}{*}{$\begin{array}{l}\text { Okres } \\
\text { Period }\end{array}$} & \multicolumn{3}{|c|}{$\begin{array}{l}\text { Mężczyźni } \\
\text { Males }\end{array}$} & \multicolumn{3}{|c|}{$\begin{array}{l}\text { Kobiety } \\
\text { Females }\end{array}$} \\
\hline & 80 & 90 & 100 & 80 & 90 & 100 \\
\hline $1952-53$ & 17529 & 2505 & 69 & 28131 & 5514 & 272 \\
\hline $1960-61$ & 23583 & 3972 & 132 & 37089 & 7877 & 323 \\
\hline $1970-72$ & 22808 & 3766 & 153 & 41661 & 9459 & 337 \\
\hline 1980-81 & 23506 & 3791 & 133 & 46768 & 12613 & 803 \\
\hline 1990-91 & 22730 & 4682 & 294 & 47642 & 15737 & 1777 \\
\hline 2000 & 28572 & 6623 & 307 & 53658 & 16238 & 633 \\
\hline 2005 & 32044 & 8054 & 374 & 58763 & 20386 & 1067 \\
\hline 2010 & 35573 & 9805 & 534 & 62324 & 23986 & 1744 \\
\hline 2013 & 38058 & 11208 & 705 & 63636 & 26243 & 2282 \\
\hline
\end{tabular}

Źródło: tablice trwania życia GUS z odpowiednich lat.

Source: official Polish life tables from the respective years, published by the CSO. 
Wzrost liczby osób bardzo starych to rezultat nie tylko obniżających się prawdopodobieństw zgonu przed osiągnięciem zaawansowanego wieku, lecz również tego, iż w dzisiejszej Polsce - wzorem innych rozwiniętych państw o niskim poziomie umieralności (Vaupel 2010) - redukcja umieralności i wydłużanie się trwania życia skoncentrowane są przede wszystkim po 60. roku życia, a w przypadku kobiet wręcz po 80. roku życia (Szukalski 2010, Wróblewska 2009). Choć prawdopodobieństwo zgonu w kolejnym roku życia obniżyło się w trakcie ostatnich dwóch dekad wśród polskich nestorów o 15-25\% (zob. rys. 2), to te znacznie wyższe zmiany prawdopodobieństw zgonu na nieco wcześniejszym etapie życia decydują o dzisiejszej liczbie dożywających do 80, 85 czy 90 lat. Tym samym ma miejsce szybki wzrost prawdopodobieństwa dożycia do bardzo zaawansowanego wieku (tablica 2).

Rysunek 2. Prawdopodobieństwo zgonu według wieku i płci w 2013 roku, jako \% wartości z 1990 roku

Figure 2. Age- and sex-specific probability of death in 2013 (as a per cent of the 1990 value)

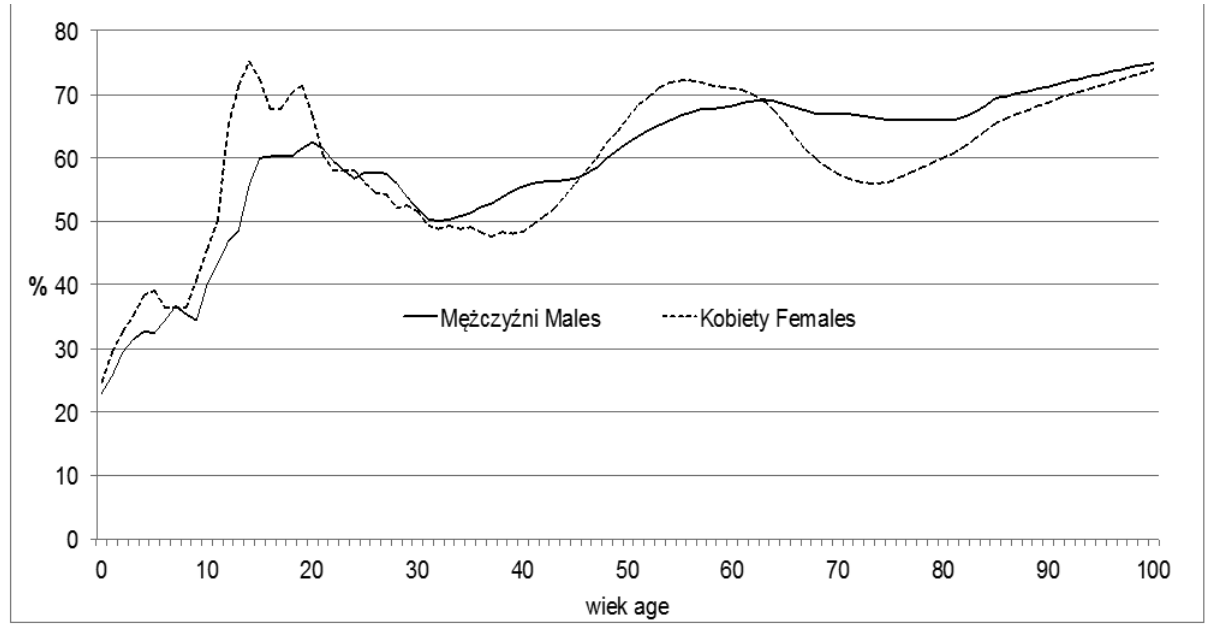

Źródło: obliczenia własne na podstawie tablic trwania życia GUS z odpowiednich lat.

Source: own calculations based on the official Polish life tables from the respective years published by the CSO.

Wzrost liczby najstarszych Polaków odzwierciedla również zmiany umieralności po 80. roku życia, które w syntetyczny sposób można przedstawić za pomocą przeciętnego dalszego trwania życia w wieku 80 (rys. 3).

Ostatnie dwudziestolecie to okres trwałego wydłużania się przeciętnego dalszego trwania życia osób osiemdziesięcioletnich, które wzrosło o blisko połowę (dla mężczyzn z 5,61 roku w 1990 roku do 7,48 roku w 2013 roku, dla kobiet odpowiednio z 6,87 do 9,10). Patrząc na przywołane szacunki, mówiące o wpływie obniżania się 
umieralności wśród osób bardzo starych na utrzymanie się wzrostu przeciętnego dalszego trwania życia noworodka (Szukalski 2010, Wróblewska 2009), przyjąć można, że tempo wzrostu przeciętnego dalszego trwania życia osiemdziesięciolatków nie obniży się przynajmniej przez najbliższych kilkanaście lat. Tyle bowiem - przy założeniu się utrzymywania typowych przyrostów bezwzględnych odnotowywanych w ostatnich latach - potrzebne jest do osiągnięcia wartości przeciętnego dalszego trwania życia nestorów rejestrowanych dzisiaj w przodujących pod tym względem państwach Europy. Na przykład we Francji w latach 2010-2012 przeciętne dalsze trwanie życia mężczyzn w wieku 80 lat wynosiło 8,57 roku, zaś kobiet 10,72 roku (INED 2015).

Rysunek 3. Przeciętne dalsze trwanie życia w wieku 80 lat według płci w latach 1950-2013

Figure 3. Life expectancy at the age of 80 by sex, 1950-2013

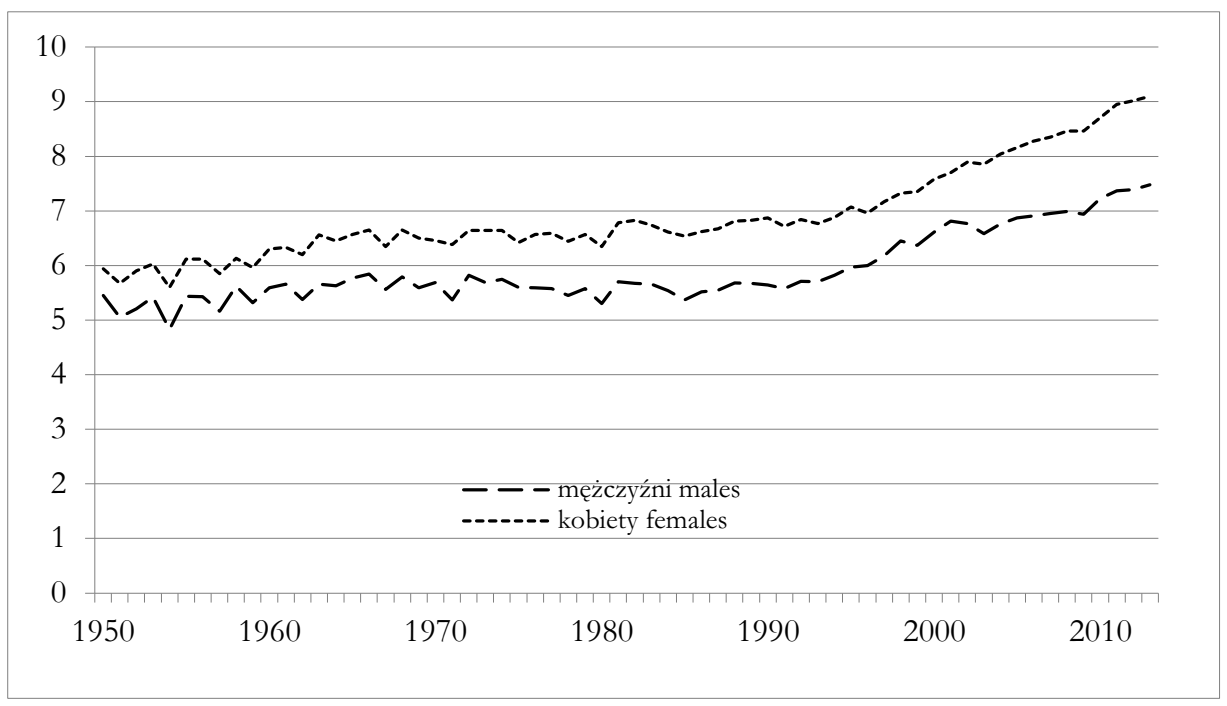

Źródło: Kędelski (1995), tablice trwania życia GUS z odpowiednich lat.

Source: Kędelski (1995), official Polish life tables from the respective years published by the CSO.

W dalszej części niniejszego artykułu odejść chciałbym od „demografii” późnej starości, koncentrując się na praktycznych problemach, jakie pojawiają się - a zwłaszcza będą się wyłaniać - wraz ze wzrostem liczby „sędziwych starców”, a z jakimi borykać się będą adepci polityki społecznej. Należy zmienić używaną do tej pory cezurę wieku zaawansowanej starości, albowiem prawna granica odróżniająca osoby nie w pełni samodzielne od reszty seniorów to 75 lat. 


\section{NOWI BENEFICJENCI UPRAWNIENI DO WSPARCIA}

Pierwszą, pozostającą $\mathrm{w}$ bezpośrednim związku z prezentowaną powyżej problematyką ilościowych zmian, kwestią jest fakt, iż liczba osób bardzo starych, które będą uzyskiwać uprawnienia do publicznego wsparcia, będzie wzrastać w najbliższych latach bardzo dynamicznie (rys. 4). W trakcie kolejnego dziesięciolecia liczba osób dożywających wieku 75 lat, a zatem wieku uprawniającego do starania się o świadczone przez gminy usługi opiekuńczo-pielęgnacyjne, jak i uzyskujących wypłacany automatycznie przez ZUS i KRUS dodatek pielęgnacyjny, prawie podwoi się. Oznacza to szybki wzrost nowych, potencjalnych beneficjentów, wymagających na pierwszym etapie wspierania większej pracy pracowników socjalnych (przygotowanie dokumentacji, przeprowadzenie wywiadu środowiskowego, itp.). W tym samym okresie liczba osób w wieku 85 lat i więcej wzrośnie ponad dwukrotnie. Są to osoby, które zgodnie ze wszelkimi badaniami wymagają w zasadzie w całości codziennego wsparcia w mniej lub bardziej intensywnej postaci, co w polskich realiach przejawia się mniej więcej dwukrotnie wyższym odsetkiem osób w tym wieku deklarujących otrzymywanie wsparcia ze strony ośrodków pomocy społecznej w porównaniu z młodszymi seniorami (Błędowski 2012: 461). W rzeczywistości, uwzględniając wspomniane wcześniej niedoszacowanie spadku umieralności, faktyczny wzrost liczby beneficjentów będzie wyższy. Zmiany te przekładać się będą również na duży - przy założeniu stałego poziomu częstości niepełnosprawności lub nawet w sytuacji poprawy stanu zdrowia - wzrost zapotrzebowania na wsparcie w domach pomocy społecznej (Szweda-Lewandowska 2009).

Zmiany te będą prowadzić na początku lat 20. XXI wieku do szybkiego wzrostu liczby nowych beneficjentów pomocy społecznej, wynikającego po części z osiągania wieku uzyskiwania uprawnień do usług opiekuńczo-pielęgnacyjnych przez osoby urodzone w trakcie powojennego wyżu demograficznego. Stanie się tak, o ile nie zostaną wdrożone propozycje odejścia od automatycznego przyznawania niektórych świadczeń (usług opiekuńczo-pielęgnacyjnych na poziomie gmin, dodatku pielęgnacyjnego na poziomie kraju) po przekroczeniu wieku 75 lat niezależnie od rzeczywistego stanu sprawności i potrzeb, zgodnie z propozycjami zespołu kierowanego przez senatora M. Augustyna. 
Ludzie bardzo starzy - niewidoczna grupa docelowa polityki społecznej?

Rysunek 4. Liczba osób dożywających wieku 75 i 85 lat w Polsce w latach 2010-2035

Figure 4. Number of persons surviving to the age of 75 and 85 years in Poland, 2010-2035

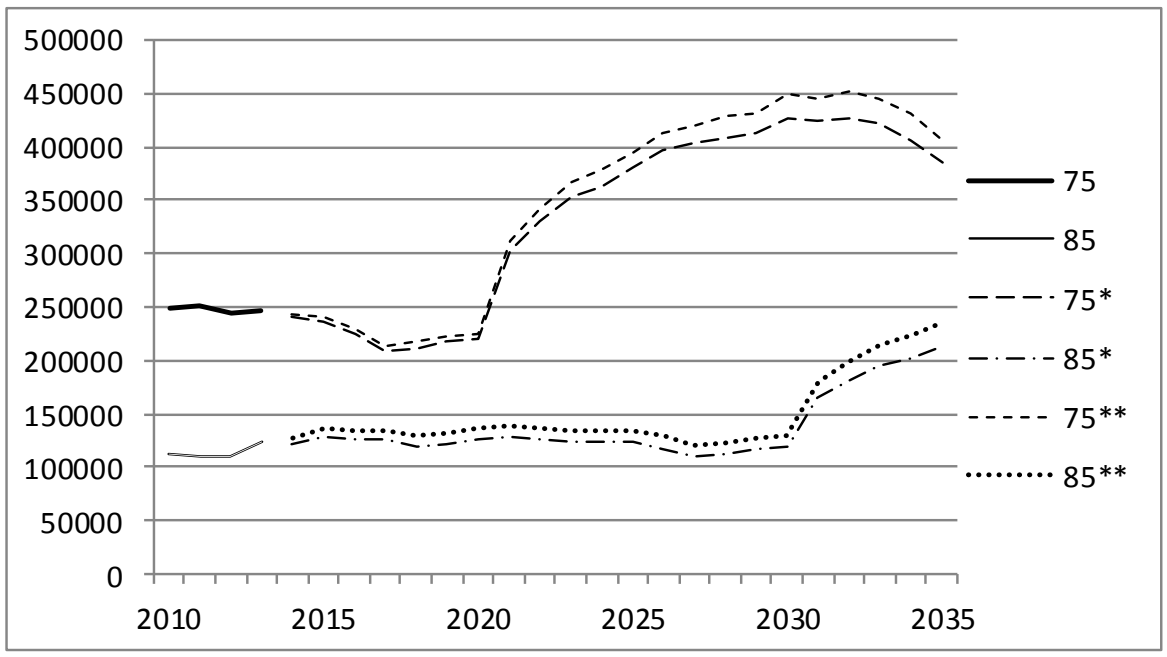

* Wartości prognozy GUS z 2008 roku. ** Wartości prognozy GUS z 2014 roku.

** Results of the 2008 CSO forecast. ** Results of the 2014 CSO forecast.

Źródło: dane Narodowych Spisów Powszechnych, GUS (2014a,c).

Source: data from population censuses, GUS (2014a,c).

\section{STAN ZDROWIA OSÓB BARDZO STARYCH}

Pomimo postępującej poprawy ogólnego stanu zdrowia populacji, ludzie bardzo starzy to osoby o poważnych problemach zdrowotnych. W Narodowym Spisie Powszechnym z 2002 roku (NSP 2002) niepełnosprawność deklarowało 50,6\% osób w wieku przynajmniej 80 lat. Według Narodowego Spisu Powszechnego z 2011 roku (NSP 2011) odsetek ten był niższy i wynosił 44,1\% (GUS 2013: 148-149). Zaznaczyć przy tym należy, iż w tej zbiorowości bardzo wysoki jest udział jednostek o niepełnosprawności tylko biologicznej (50,2\% w 2011 roku), przewyższający nieco frakcję tych, którzy - odczuwając ograniczenia codziennego funkcjonowania - posiadają stosowne orzeczenie wydane przez odpowiedni organ $(45,2 \%)$, oraz wielokrotnie przewyższający frakcję tych, którzy - takowe orzeczenie posiadając - nie odczuwają rzeczywistych ograniczeń (4,6\%), a zatem niepełnosprawnych tylko prawnie. Wiele osób nie widzi zatem korzyści z podejmowania starań o uzyskanie prawnego potwierdzenia niepełnosprawności po uprzednim uzyskaniu uprawnienia do dodatku pielęgnacyjnego.

$20 \%$ niepełnosprawnych, sędziwych starców w Polsce to osoby odczuwające calkowitą niepełnosprawność. Nieco wyższy udział tej grupy znajdujemy w zbiorowo- 
ści kobiet, co związane jest z wyższym odsetkiem jednostek mających przynajmniej 85 lat. Generalnie widoczny jest wyraźny związek niepełnosprawności i wieku - im starsze jednostki, tym wyższa frakcja osób deklarujących całkowitą niepełnosprawność i niższa frakcja osób nieodczuwających ograniczeń sprawności.

Z niepełnosprawnością zazwyczaj współwystępuje inne zjawisko typowe dla osób bardzo starych. Jest to wielochorobowość, czyli współwystępowanie kilku przewlekłych chorób (Wieczorkowska-Tobis 2011). Jest to zazwyczaj tzw. efekt domina polegający na tym, iż załamanie się równowagi zdrowotnej przez uszkodzenie/chorobę jednego narządu u osób bardzo starych, odznaczających się brakiem rezerw fizjologicznych, często pociąga za sobą lawinowe narastanie uszkodzeń/chorób innych narządów. Wielochorobowość nie tylko wyraźnie ogranicza jakość życia i samodzielność sędziwych starców, lecz dodatkowo jest skomplikowana w leczeniu z uwagi na synergię problemów zdrowotnych i trudność ustalenia rezultatów interakcji pomiędzy sposobami leczenia, zwłaszcza między lekami. Wielolekowość, czyli jednoczesne pobieranie przynajmniej 5 leków, dotyczy 3/4 osób w wieku 80 lat i więcej w Polsce (Rajska-Neumann $\mathrm{i}$ in. 2012: 387) i wraz z wielochorobowością tworzy „spiralę chorób i terapii”, czyli sytuację, w której każda kolejna choroba wymaga wizyty u lekarza specjalisty, zaś stosowanie kolejnych leków zwiększa prawdopodobieństwo efektów ubocznych, prowadzących do nowych problemów zdrowotnych. W rezultacie, jak wskazuje badanie stanu zdrowia ludności z 2009 roku (GUS 2011: 120-121) - 92,6\% mężczyzn i 94,1\% kobiet w badanym wieku deklaruje występowanie długotrwałych problemów zdrowotnych. Ograniczając się tylko do tych problemów, które dotykają przynajmniej $10 \%$ zbiorowości najstarszych Polaków, uzyskujemy informację o skali najczęstszych chorób przewlekłych:

- wysokie ciśnienie krwi $(55,3 \%)$,

- choroba wieńcowa $(44,9 \%)$,

- zapalenie kości i stawów $(42,0 \%)$,

- bóle pleców (38,7\%),

- reumatoidalne zapalenie stawów $(26,7 \%)$,

- bóle szyi $(21,3 \%)$,

- nietrzymanie moczu, problemy z kontrolowaniem pęcherza $(18,8 \%)$,

- cukrzyca $(16,0 \%)$,

- choroba prostaty $(11,1 \%)$.

Powyższe zestawienie jednoznacznie potwierdza wysoką skalę współwystępowania wielu przewlekłych problemów zdrowotnych w tym wieku. W rezultacie, samopoczucie psychiczne sędziwych starców jest generalnie niskie, a 48,4\% badanych nigdy nie odczuwa dobrego samopoczucia (GUS 2011: 191).

Przedstawione wyżej zjawisko wielochorobowości, choć jest zazwyczaj kojarzone z osiąganiem bardzo zaawansowanego wieku, nie spotyka się z praktycznymi działaniami, takimi jak przygotowanie lekarzy pierwszego kontaktu, pomocniczego personelu medycznego czy pracowników socjalnych do świadczenia usług na rzecz 
osób bardzo starych z uwzględnieniem ich specyficznych dolegliwości czy specyficznego sposobu leczenia. O ile brak geriatrów dotarł do świadomości decydentów (o czym świadczą zapowiedzi widoczne w exposé E. Kopacz) i potencjalnych pacjentów, o tyle przygotowanie lekarzy pierwszego kontaktu, lekarzy specjalistów i innych służb medycznych do uwzględniania specjalnego sposobu dawkowania leków lub swoistych interakcji pomiędzy lekami przepisywanymi przez różnych specjalistów, jest wciąż mało powszechne. Problemy z dozowaniem leków choć częściowo zmniejszyć może wprowadzenie kart chipowych dla pacjentów, dzięki którym lekarze poznają historię medyczną swych sędziwych klientów, lecz nawet to udogodnienie nie wyeliminuje konieczności uwzględniania przez lekarzy specyfiki dawkowania leków.

Brak jest również specjalnych szkoleń przygotowujących pracowników socjalnych do nadzoru osób opiekujących się osobami sędziwymi. O ile w ostatnich latach, głównie dzięki projektom dofinansowywanym przez Unię Europejską i skierowanym na aktywizację społeczną i funkcjonalną osób na przedpolu starości, pojawiło się wiele - mniej lub bardziej profesjonalnie prowadzonych - kursów opieki nad osobami starszymi, o tyle wciąż brak jest oferty zajęć dla pracowników socjalnych. Nawet wprowadzenie przez Ministerstwo Pracy i Pomocy Społecznej „pracy socjalnej z osobami niepełnosprawnymi i starszymi” do katalogu specjalizacji pracy socjalnej nie zmienia obecnej sytuacji, albowiem - jak wskazuje przegląd realizowanych przez Regionalne Ośrodki Polityki Społecznej studiów podyplomowych, ukierunkowanych na wsparcie pracowników socjalnych w uzyskaniu specjalizacji - pracownicy ci zdecydowanie preferują pracę $\mathrm{z}$ dziećmi i z rodzinami, nie zdając sobie zapewne sprawy z kierunku i skali przyszłych przemian demograficznych.

\section{KTO BĘDZIE SIĘ OPIEKOWAĆ NAJSTARSZYMI STARYMI?}

Praktycznym problemem, o którym się zazwyczaj nie myśli, jest kwestia sprawowania opieki nad sędziwymi starcami, którzy za kilkanaście lat będą niezdolni do samodzielnego funkcjonowania. Jak wskazują wyniki badania PolSenior, w przypadku osób po 75. roku życia odsetek zamieszkujących samotnie pozostaje w zasadzie taki sam aż do wieku 90 lat i więcej, natomiast zmniejsza się wraz $\mathrm{z}$ wiekiem częstość zamieszkiwania wraz z małżonkiem, co z kolei jest w około 3/4 przypadków rekompensowane zwiększaniem się odsetka sędziwych starców zamieszkujących ze swymi dziećmi (Szatur-Jaworska 2012: 424).

Pierwsza ze wspomnianych prawidłowości nie dziwi, jeśli pamiętamy o szybko rosnącej wraz z wiekiem skali wdowieństwa (Szukalski 2013b). Z jednej strony, w przyszłości należy oczekiwać - tak jak to miało miejsce między realizacją spisu powszechnego w 1988 i 2011 roku, czyli w okresie znaczącego spadku umieralności - powolnego zmniejszania skali wdowieństwa wskutek coraz późniejszego 
występowania zgonu małżonka ${ }^{5}$. Z drugiej strony, w przyszłości interesujący nas wiek osiągać będą generacje odznaczające się w trakcie całego dorosłego życia zdecydowanie wyższym niż w przypadku dotychczasowych „sędziwych starców” prawdopodobieństwem rozpadu związku wskutek rozwodu (Szukalski 2013b). Równocześnie nie należy mieć złudzeń co do możliwości znacznego upowszechnienia się związków nieformalnych w tym wieku jako remedium na wdowieństwo i samotność, ponieważ według NSP 2011 frakcja najstarszych Polaków żyjących w związkach kohabitacyjnych nie przekracza jednego promila (GUS 2013b: 232-233).

Z kolei, w przypadku drugiej prawidłowości zdawać sobie należy sprawę z tego, że postępująca $\mathrm{w}$ drugiej połowie $\mathrm{XX}$ wieku redukcja dzietności przekładać się będzie na niższe możliwości odwołania się do pomocy własnego potomstwa, zwłaszcza w środowiskach wielkomiejskich. Niższa liczba dzieci oznacza mniejszą szansę, iż którekolwiek $\mathrm{z}$ nich podejmie się trudu opieki, nawet w sytuacji, nadmiernie optymistycznej, w której siła zobowiązań wobec własnych rodziców nie osłabnie.

Powyższe zmiany będą negatywnie wpływać na możliwość zapewnienia opieki, albowiem jedynie redukcja umieralności będzie zwiększać prawdopodobieństwo posiadania żyjącego małżonka, rodzeństwa, potomstwa i przyjaciół. W tym przypadku zdawać sobie należy sprawę, iż - pomijając potomków - pozostałe osoby bliskie sędziwym seniorom będą $\mathrm{z}$ reguły $\mathrm{w}$ bardzo podobnym wieku, a zatem nie należy oczekiwać z ich strony intensywnej pomocy. Pojawi się zatem już dziś widoczna potrzeba rozbudowywania sieci wsparcia poza grono jednostek przynależących do tej samej grupy wieku.

Wiele osób osiągających w najbliższych dekadach bardzo zaawansowany wiek będzie doświadczać skutków upowszechniania się rodzin światowych. Termin ten, autorstwa U. Becka i E. Beck-Gernsheim (2013), odnosi się do takich rodzin, w których relacje przebiegają ponad granicami tradycyjnych, narodowych państw, a zatem w przypadku których występuje oddzielenie przestrzenne członków. Wśród dzisiejszych sześćdziesięcio- i siedemdziesięciolatków sporo jest osób, które w trakcie ostatniego ćwierćwiecza, a zwłaszcza w okresie mijającej dekady przynależności Polski do Unii Europejskiej doświadczyły wyjazdu na stałe dzieci lub wnuków poszukujących szczęścia na obczyźnie. Nowoczesne technologie umożliwiają obecnie utrzymanie stałego kontaktu z członkami rodzin zamieszkujących w różnych krajach, niwelując wpływ odległości migracji. Jednak gdy za lat kilka, kilkanaście pokolenie pozostałe w Polsce osiągnie odpowiednio zaawansowany wiek, charakteryzujący się wysokim zapotrzebowaniem na wsparcie, okaże się, że ich rodziny - i tak słabiej „demograficznie przygotowane” do opieki ze względu na małodzietność - nie będą w stanie tego wsparcia udzielić z uwagi na odległość.

5 Pamiętać należy jednak w tym przypadku o różnicy pomiędzy sytuacją kobiet i mężczyzn. Nadumieralność tych drugich oraz kulturowe preferencje dla małżeństw odznaczających się różnicą wieku z młodszą żoną prowadzą do zdecydowanie wyższego udziału osób owdowiałych w zbiorowości kobiet w porównaniu z ich rówieśnikami płci męskiej. 
Oczekiwany w przyszłości wzrost realnej wartości płac w Polsce może uniemożliwić zastąpienie samodzielnie świadczonej opieki przez transfery materialne, przeznaczone na zakup usług oferowanych przez innych. Sprawi to, iż finansowanie z prywatnych środków komercyjnej opieki nie będzie tak łatwe jak obecnie, gdy wciąż istnieją duże różnice między siłą nabywczą wynagrodzeń w Polsce i krajach Europy Zachodniej.

Trzy czynniki: wzrost wartości płac, poprawiająca się sytuacja na rynku pracy oraz zmniejszenie się liczby potencjalnych opiekunów rodzinnych wskutek długookresowych przemian wielkości i struktury sieci rodzinnej (co w analizach makrospołecznych znajduje wyraz w obniżaniu się wartości współczynników potencjału pielęgnacyjnego) będą działać na rzecz wzrostu znaczenia imigrantów jako osób świadczących usługi opiekuńcze i pielęgnacyjne. Pomijając możliwy napływ imigrantów z Ukrainy czy Mołdowy, choć duża skala tego napływu wzbudza wątpliwości, główne strumienie migracji przyszłych opiekunów pochodzić będą z innych części świata. Oznaczać to będzie, iż w perspektywie kilkunastu lat pracownicy socjalni organizujący sieć usług opiekuńczo-pielęgnacyjnych dla potrzebujących nestorów coraz częściej stykać się będą z „dalekimi innymi”, osobami z innych kręgów kulturowych i językowych. Wątpliwe jest to, iż owi pracownicy są przygotowani do tego typu kontaktów mentalnie, kulturowo, językowo.

\section{ZWIĘKSZAJĄCA SIĘ LICZBA ZGONÓW W PÓŹNYM WIEKU}

Przedstawione wcześniej przemiany demograficzne prowadzić będą również do zwiększającej się liczby zgonów w bardzo zaawansowanym wieku. Warto przyjrzeć się pomijanym zazwyczaj tego konsekwencjom. Już dzisiaj, tj. w roku 2013, 40,6\% wszystkich zgonów przypada na wiek 80 lat i więcej, przy czym dotyczy to $27,3 \%$ zgonów mężczyzn i 55,0\% zgonów kobiet. W 1970 roku jedynie 18,5\% zgonów miało miejsce po 80 . roku życia, a w roku $1990-29,5 \%{ }^{6}$. Wraz ze wzrostem szans dożycia do bardzo zaawansowanego wieku oraz z osiąganiem tego wieku przez liczne generacje urodzone po II wojnie światowej oczekiwać należy, iż coraz więcej zgonów będzie przypadać na ten właśnie okres życia. Odsetek zgonów po 80. roku życia jest wyższy w państwach europejskich bardziej zaawansowanych w procesie się starzenia ludności, na przykład w Szwecji $(60,8 \%)$, we Francji $(57,0 \%)$, w Wielkiej Brytanii (54,8\%) czy w Niemczech (52,7\%) (Eurostat 2014). W Polsce udział ten będzie wzrastać i osiągnie według prognozy GUS 53,6\% w roku 2035 (prognoza z 2008 roku) lub nawet $62,5 \%$ (prognoza z 2014 roku) ${ }^{7}$. Liczba umierających osób

6 Jako ciekawostkę warto dodać, iż w 1931 roku było to tylko 5,8\% ogółu zgonów (GUS 1939: 96).

7 W dostępnych założeniach prognoz z 2008 i 2014 roku brak jest informacji o liczbie zgonów według wieku, zaś obliczona na potrzeby niniejszego tekstu wielkość bazuje na założeniu o braku migracji zewnętrznych po 80. roku życia, co jest bliskie rzeczywistym procesom (Kałuża 2006). W takim 
w wieku przynajmniej 80 lat od 2029 roku przekraczać ma 200 tys. rocznie, osiągając ćwierć miliona w roku 2035 (rys. 5).

Rysunek 5. Liczba zgonów ogółem i osób bardzo starych w latach 2008-2035

Figure 5. Death counts for entire population and the oldest old in Poland, 2008-2035

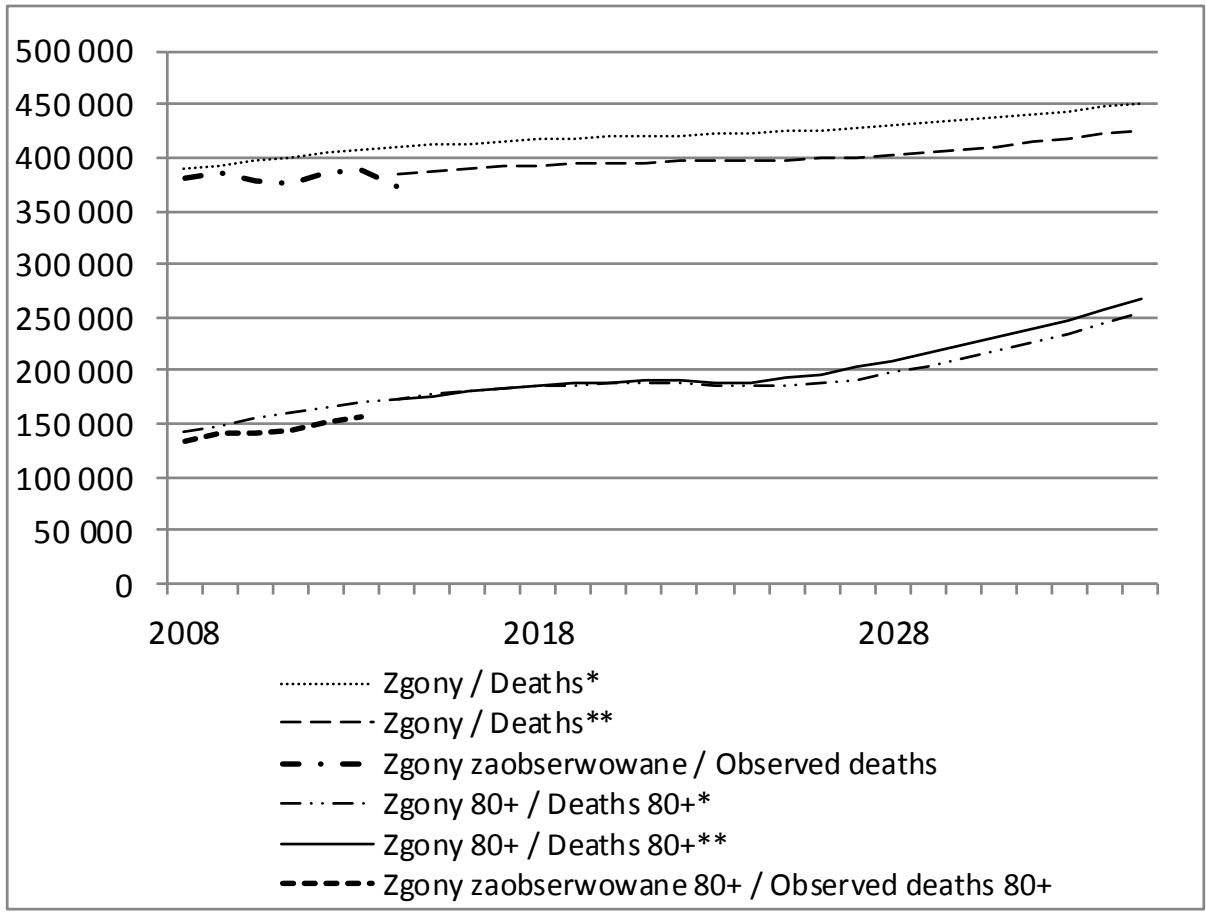

* Wartości prognozy GUS z 2008 roku. ** Wartości prognozy GUS z 2014 roku.

** Results of the 2008 CSO forecast. ** Results of the 2014 CSO forecast.

Źródło: dane Narodowych Spisów Powszechnych, GUS (2014a,c).

Source: data from population censuses, GUS (2014a,c).

Problematyka zgonów osób bardzo starych jest całkowicie zmarginalizowana, a tymczasem, nawet zakładając poprawę stanu zdrowia i sprawności w długim okresie, liczba zgonów jest znakomitym predyktorem zapotrzebowania na wzmożoną, specjalistyczną, długotrwałą opiekę nad sędziwymi starcami. Zazwyczaj bowiem 2 ostatnie lata życia są okresem wzmożonego zapotrzebowania na usługi medyczne, pielęgnacyjne i opiekuńcze. Niewiele wiemy o okolicznościach, w jakich umierają osoby w wieku zaawansowanym, ani o tym, jak wyglądają ich ostatnie tygodnie

przypadku, wszystkie osoby, które w roku $x$ miały przynajmniej 79 lat, w roku $x+1$ mieć będą 80 lat. Znając prognozowaną liczbę osób w wieku 80 lat i więcej, obliczyć można różnicę, która przy powyższym założeniu mówi o przybliżonej liczbie zgonów w interesującym nas wieku (przybliżonej, albowiem w rzeczywistości w zbiorowości tej znajdzie się połowa zgonów w wieku 79 lat). 
i miesiące. Dostępne opracowania (Kalbarczyk-Stęclik, Nicińska 2013) odnoszą się do podstawowych charakterystyk okoliczności, nie różnicując ich w zależności od wieku, niemniej pozwalają na stwierdzenie, iż w przypadku połowy przyczyn zgonów choroba prowadząca bezpośrednio do zgonu trwa przynajmniej pół roku.

Mówiąc o owych okolicznościach, w pierwszej kolejności wspomnieć trzeba o miejscu zgonu. W dalekiej przeszłości prawie wszystkie zgony miały miejsce w domu, zaś śmierć w otoczeniu rodziny była - pomijając śmierć naglą, we śnie - swoistym ideałem, umożliwiającym godne pożegnanie się z domownikami. Po części sytuacja taka wynikała z braku lub słabości opieki instytucjonalnej, w efekcie czego rodzina była najważniejszą, niekiedy jedyną instytucją, w ramach której opiekowano się osobą w ostatniej fazie życia. Jednakże w ostatnich dekadach w Polsce coraz powszechniejsza jest tzw. medykalizacja śmierci, polegająca na coraz częstszym powiązaniu prowadzących do zgonu chorób $\mathrm{z}$ długotrwałą i bezpośrednią interwencją specjalistów z zakładów zamkniętej opieki medycznej.

Tablica 4. Liczba i odsetek zgonów według miejsca śmierci w Polsce w latach 1980-2013

Table 4. Number and percentage of deaths by place of death, Poland, 1980-2013

\begin{tabular}{|c|c|c|c|c|c|}
\hline \multirow[b]{2}{*}{$\begin{array}{l}\text { Rok } \\
\text { Year }\end{array}$} & \multirow{2}{*}{$\begin{array}{l}\text { Liczba zgonów } \\
\text { (w tys.) } \\
\text { Number of deaths } \\
\text { (in thousands) }\end{array}$} & \multicolumn{4}{|c|}{ Jako \% ogółu zgonów As a per cent of all deaths } \\
\hline & & $\begin{array}{l}\text { W szpitalu } \\
\text { At a } \\
\text { hospital }\end{array}$ & $\begin{array}{l}\text { W innym zakładzie } \\
\text { opieki zdrowotnej } \\
\text { In other medical } \\
\text { institution }\end{array}$ & $\begin{array}{l}\mathrm{W} \text { domu } \\
\text { At home }\end{array}$ & $\begin{array}{c}\mathrm{W} \text { innym } \\
\text { miejscu } \\
\text { In other places }\end{array}$ \\
\hline 1980 & 353,2 & 42,7 & 0,5 & 49,1 & 6,9 \\
\hline 1990 & 390,3 & 46,6 & 1,5 & 45,2 & 6,2 \\
\hline 2000 & 368,0 & 50,1 & 3,0 & 40,9 & 6,0 \\
\hline 2010 & 378,5 & 50,2 & 6,2 & 37,8 & 5,8 \\
\hline 2013 & 387,3 & 50,9 & 7,3 & 36,5 & 5,3 \\
\hline
\end{tabular}

Źródło: obliczenia własne na podstawie GUS (2014c: 428).

Sources: own calculations based on GUS (2014c: 428).

W efekcie medykalizacji ostatniej fazy życia następował w ostatnich dekadach wzrost znaczenia szpitali i innych zakładów opieki medycznej (przede wszystkim hospicjów) i spadek znaczenia domu jako miejsca zgonu (tablica 4). Brak jest dostępnych danych na temat dokładnego rozkładu wieku umierających w zależności od miejsca zgonu, lecz domniemywać można, iż zwiększanie się odsetka osób bardzo starych wśród umierających współwystępuje z coraz częstszym ich pobytem w szpitalach lub pozostałych zakładach opieki medycznej. Domniemanie powyższe bazuje na założeniu, iż w przypadku zgonów osób bardzo starych zdecydowanie częściej występują przyczyny zgonów przewidywalne (Szukalski 2007), o ile wręcz 
nie takie, które na ostatnim etapie rozwoju jednostki chorobowej wiążą się z częstym i długim pobytem w specjalistycznych placówkach. Potwierdzają to wyniki badań pochodzące z Francji (Pennec i in. 2013), gdzie wysoce zaawansowany wiek wpływał przede wszystkim na szybki wzrost odsetka umierających w domach opieki.

W rezultacie wspomnianej medykalizacji zmniejsza się obciążenie rodziny opieką nad umierającymi. Jednocześnie podejrzewać można, iż wskutek zaniku naturalnego w minionych epokach historycznych zjawiska „oswojenia śmierci”, tj. częstego się z nią stykania, asystowania przy agonii najbliższych, czuwania przy zwłokach, stres psychiczny wynikający z utraty bliskiej osoby nie zmniejszył się, lecz wręcz przeciwnie - narasta. Stres ten zapewne jest znacząco większy również i w przypadku osób umierających, których ostatnie dni i godziny życia coraz częściej upływają w obcym otoczeniu.

Zmarginalizowaną, o ile w ogóle analizowaną przez adeptów polityki społecznej, kwestią jest wsparcie udzielane osobom umierającym i ich rodzinom (Walsh 2011). Większość umierających w Polsce swe ostatnie dni spędza w szpitalu, zaś mimo postępującej poprawy instytucje te nie potrafią zapewnić umierającym i członkom ich rodzin godnych warunków do przygotowania się do śmierci. Większość osób chce umierać w domu, jednakże w przypadku wielu chorób (przede wszystkim nowotworowych) wymagających opieki paliatywnej w ostatnim stadium rozwoju (Pennec i in. 2013) nie pomaga się rodzinnym opiekunom w zakresie obsługi sprzętu medycznego czy podawania leków, w sytuacji gdy podawanie doustne nie jest możliwe.

Całkowicie pozostawione sobie są osoby owdowiałe i osierocone przez sędziwych starców, dla których opieka była w ostatnich latach życia zmarłego często najważniejszą działalnością. Pustka, jaką odczuwają po utracie bliskiej osoby, połączona z normalnym w takiej sytuacji rozliczaniem się z tego, na ile się zrobiło wszystko, co możliwe, w celu przedłużenia życia albo ulżenia cierpieniom, zostawiona jest sobie samej. Tymczasem znaleźć można w innych krajach dobre przykłady pracy socjalnej z osobami umierającymi i ich opiekunami, przygotowującej je do rozstania się z bliskimi bez wyrzutów o niewykorzystanie wszystkich możliwości pomocy. Istnieją też przykłady wykorzystywania wolontariatu na rzecz długotrwale chorych osób niespokrewnionych jako swoistego narzędzia łagodzenia wewnętrznych rozterek (Wolfer i Runnion 2008). Jest to jednak przejaw generalnej słabości pracy socjalnej w Polsce, jaką jest niedocenianie roli terapii, czy szerzej wsparcia psychologicznego dla potrzebujących.

Dodatkowo, $\mathrm{z}$ reguły na marginesie zainteresowań, pozostawiane są kwestie etyczne związane $\mathrm{z}$ osiąganiem bardzo zaawansowanego wieku przez duże grupy ludności. Kwestie te nierozerwalnie związane są z warunkowością intensywnej, kosztownej opieki medycznej. Już dziś w oddziałach intensywnej opieki medycznej łóżka „okupowane” są przez nestorów zajmujących je przez dni, tygodnie, miesiące, bardzo często na usilne żądanie rodziny, szantażującej lekarzy pozwami sądowymi 
w przypadku przerwania intensywnej kuracji ${ }^{8}$. Oddziały internistyczne nie są przygotowane na przyjęcie dodatkowej liczby długookresowych pacjentów. Dużą ich część i tak stanowią osoby w wieku sędziwym, które z uwagi na obiektywny brak opiekunów lub niemożność/niechęć rodziny do wykonywania opieki pozostają zdecydowanie dłużej w jednostkach opieki medycznej, niż wymaga tego ich stan zdrowia. Wszystkie oddziały szpitale bronią się przed pacjentem geriatrycznym jako pacjentem wielochorobowym, narażającym instytucję na wysokie wydatki w sytuacji otrzymywania zwrotu kosztów za procedury medyczne związane z leczeniem jednej przypadłości. Niezbędna jest zatem rozbudowa zakładów opiekuńczo-leczniczych $i$ innych instytucji intensywnej opieki długookresowej przeznaczonych dla jednostek „powoli gasnących” wskutek wieku, nie zaś śmiertelnych chorób.

\section{PODSUMOWANIE}

Szybki wzrost liczby osób bardzo starych w nadchodzących dekadach wymaga przewidujących działań przygotowawczych, tymczasem - choć wyniki prognoz ludnościowych w tym względzie znane są od dawna - można mieć wrażenie, iż realizatorzy polityki społecznej różnych szczebli nie uwzględniają takich przygotowań w swych bieżących działaniach.

Dzieje się tak na różnych szczeblach polityki. Na poziomie makro polskie prawo - nie do końca w zgodzie z rzeczywistością - przyjmuje, iż osiągnięcie wieku 75 lat samoczynnie związane jest ze zrealizowanym ryzykiem niepełnosprawności i niesamodzielności, oferując każdemu automatycznie dodatek pielęgnacyjny i dając uprawnienie do korzystania $\mathrm{z}$ usług opiekuńczo-pielęgnacyjnych. Takie założenie nie znajduje potwierdzenia $\mathrm{w}$ empirii, zgodnie $\mathrm{z}$ którą dopiero przekroczenie 85. roku życia związane jest ze zdecydowanie wyższą skłonnością do korzystania ze wsparcia instytucji pomocy społecznej (Błędowski 2012). W rezultacie, zamiast pomagać naprawdę potrzebującym, przekazuje się w oparciu o kryterium wieku „publiczną jałmużnę”, niewystarczającą na sfinansowanie opieki w przypadku takiej potrzeby. W tym miejscu nasuwa się samoistnie refleksja o bardziej ogólnym charakterze, odnosząca się do coraz wyraźniejszego mijania się tradycyjnych opinii na temat początku starości, w tym i tej niedołężnej, z rzeczywistością. Owe tradycyjne opinie po dziś dzień kształtują prawo, które na podstawie doświadczeń sprzed wielu dekad i odnoszących się do innych realiów społecznych, kulturowych i demograficznych, określa cezurę wieku określającą możliwość korzystania z różnych uprawnień. Tymczasem ma miejsce obecnie dyskusja na temat tego, kiedy zaczyna się (niesamodzielna) starość (Szukalski 2012), jak ją mierzyć (na przykład przez odwoływanie się

8 Słowa te formułuje na podstawie swych doświadczeń jako członka Rady Łódzkiego Oddziału Narodowego Funduszu Zdrowia. 
do wieku potencjalnego/prospektywnego, Abramowska-Kmon 2011) i oddziaływać na jej przebieg.

Na poziomie mezo słabo uwzględnia się specyfikę potrzeb osób bardzo starych. Na terenach wiejskich wręcz uznaje się, iż rodzina jest a priori jedynym dostarczycielem pomocy osobom sędziwym (Krzyszkowski 2011). Aktywizowanie seniorów ograniczane jest głównie do Uniwersytetów Trzeciego Wieku, zaś zdecydowanie rzadsze są działania przeznaczone dla osób mniej mobilnych, gorzej wykształconych, w większym stopniu wymagających bycia z kimś w znanym sobie otoczeniu. Dzieje się tak zarówno z uwagi na wyższy koszt jednostkowy takich programów, brak przykładów dobrych praktyk, jak i nietraktowanie potrzeb osób bardzo starych jako problematyki, którą winny się zajmować inne gremia niż rodzina. Skuteczne praktyki aktywizujące/wspomagające powinny również uwzględniać pominięte w niniejszym opracowaniu cechy badanej zbiorowości, na przykład wysoki poziom feminizacji i syngularyzacji gospodarstw domowych, relatywnie niski poziom wykształcenia, problemy z poruszaniem się.

Potrzebne jest zatem uwzględnienie w systemie prawa i w praktyce jego wdrażania nowych realiów demograficznych, przejawiających się nie tylko szybkim wzrostem liczby osób bardzo starych, ale i zmianą ich indywidualnych charakterystyk, $\mathrm{z}$ których najważniejszymi $\mathrm{w}$ długim okresie jest wzrost poziomu wykształcenia i poprawa stanu zdrowia. W praktyce należy odejść od ustalania sztywnych cezur wieku starości, z którymi łączone są pewne przywileje wynikające z niepełnej samodzielności, na rzecz ustalania „twardych” warunków, jakie spełniać musi jednostka, aby uzyskać dane uprawnienia.

Jednocześnie potrzebna jest refleksja nad nowymi metodami aktywizowania w miare sprawnych „starych starych” i „najstarszych starych”. Osoby w pełni sprawne $\mathrm{z}$ reguły są $\mathrm{w}$ stanie samodzielnie zorganizować sobie czas, te mniej sprawne potrzebują informacji przekazywanej tradycyjnie, a jednocześnie prosto, o kierowanych do nich usługach społecznych wspierających ich chęć spędzania wolnego czasu poza domem.

Nade wszystko potrzebne jest podkreślanie z jednej strony przestrzennego zróżnicowania procesu zaawansowanego starzenia się ludności (Kurek 2008) i dostępności danych prognostycznych na poziomie powiatu, z drugiej zaś budowanie prognoz ostrzegawczych wskazujących na zmiany, jakie mogą wystąpić przy znacznie większej niż zakładanej redukcji umieralności. Samo bowiem porównanie obu ostatnich prognoz ludnościowych GUS dowodzi, iż relatywnie niewielkie zmiany założeń o przyszłym natężeniu zgonów prowadzą do znaczących różnic w liczbie osób dożywających zaawansowanego wieku. Wynik oznaczający dodatkowe 200 tys. sędziwych starców w perspektywie 15 lat czy 300 tys. w perspektywie 20 lat przesądza o tym, iż jako społeczeństwo powinniśmy być przygotowani na zdecydowanie większy od obecnego i zakładanego zakres zapotrzebowania na różnorodne usługi na rzecz najstarszych osób. 


\section{LITERATURA}

Abramowska-Kmon A., 2011, O nowych miarach zaawansowania procesu starzenia się ludności, „Studia Demograficzne”, nr 1/159, 3-22.

Beck U., Beck-Gernsheim E., 2013, Miłość na odległość. Modele życia w epoce globalnej, WN PWN, Warszawa.

Błędowski P., 2012, Potrzeby opiekuńcze osób starszych, [w:] M. Mossakowska, A. Więcek, P. Błędowski (red.), Aspekty medyczne, psychologiczne, socjologiczne i ekonomiczne starzenia się ludzi w Polsce (s. 449-466), Termedia, Warszawa.

Eurostat, 2014, Deaths by age and sex, zasób internetowy, http://appsso.eurostat.ec.europa.eu/nui/show. do?dataset=demo_magec\&lang=en (dostęp z dn. 15.03.2015).

GUS, 1939, Małżéstwa, urodzenia i zgony. 1931, 1932, „Statystyka Polski”, seria c, z. 102.

GUS, 2009, Prognoza ludności na lata 2008-2035, ZWS GUS, Warszawa.

GUS, 2011, Stan zdrowia ludności Polski w 2009 r., ZWS GUS, Warszawa.

GUS, 2013a, Ludność. Stan i struktura spoleczno-ekonomiczna. Cz. I. Ludność, Narodowy Spis Powszechny Ludności i Mieszkań 2011, ZWS GUS, Warszawa.

GUS, 2013b, Ludność. Stan i struktura społeczno-demograficzna. Narodowy Spis Powszechny Ludności i Mieszkań 2011, ZWS GUS, Warszawa.

GUS, 2014a, Baza Demografia, zasób internetowy, http://demografia.stat.gov.pl/bazademografia/ (dostęp $\mathrm{z}$ dn. 15.03.2015).

GUS, 2014b, Prognoza ludności na lata 2014-2050, ZWS GUS, Warszawa.

GUS, 2014c, Rocznik Demograficzny 2014, GUS, Warszawa.

INED, 2015, Table de mortalité 2010-2012, zasób internetowy, http://www.ined.fr/fr/tout-savoirpopulation/chiffres/france/mortalite-cause-deces/table-mortalite/ (dostęp z dn. 15.03.2015).

Kalbarczyk-Stęclik M., Nicińska A., 2013, Ostatni rok życia Polaków w świetle danych SHARE: analiza porównawcza, „Studia Demograficzne”, nr 1/163, 53-72.

Kałuża D., 2006, Migracje seniorów w Polsce, [w:] J.T. Kowaleski (red.), Ludzie starzy w polskim społeczeństwie w pierwszych dekadach XXI wieku (s. 151-174), Wydawnictwo Uniwersytetu Łódzkiego, Łódź.

Kędelski M., 1995, Koniunktura demograficzna w Polsce w latach 1948-1994, t. 1, Szacunki statystyczne struktury wieku i trwania życia ludności, Wydawnictwo Uniwersytetu Ekonomicznego, Poznań.

Krzyszkowski J., 2011, Osoby starsze, [w:] R. Szarfenberg (red.), Krajowy raport badawczy. Pomoc $i$ integracja spoleczna wobec wybranych grup - diagnoza standaryzacji ustug i modeli instytucji (s. 153-192), WRZOS, Warszawa.

Kurek S., 2008, Typologia starzenia się ludności Polski w ujęciu przestrzennym, WN AP, Kraków.

Pennec S., Gaymu J., Monnier A., Riou F., Aubry R., Pontone S., Cases Ch., 2013, In France, where do people live in their last month of life and where do they die?, „Population”, vol. 68, no. 4, 503-532.

Rajska-Neumann A., Wieczorkowska-Tobis K., Mossakowska M., Skalska A., Ślusarczyk P., Świech M., Grodzicki T., 2012, Farmakoterapia u osób starszych w Polsce, [w:] M. Mossakowska, A. Więcek, P. Błędowski (red.), Aspekty medyczne, psychologiczne, socjologiczne i ekonomiczne starzenia się ludzi w Polsce (s. 379-390), Termedia, Warszawa.

Szatur-Jaworska B., 2012, Sytuacja rodzinna $i$ więzi rodzinne ludzi starych $i$ osób na przedpolu starości, [w:] M. Mossakowska, A. Więcek, P. Błędowski (red.), Aspekty medyczne, psychologiczne, socjologiczne i ekonomiczne starzenia się ludzi w Polsce (s. 419-448), Termedia, Warszawa.

Szukalski P., 2004, Osoby bardzo stare w Polsce i w krajach Unii Europejskiej-przeszłość, teraźniejszość, przyszłość, „Prace Instytutu Ekonometrii i Statystyki UŁ”, nr 142, 5-33.

Szukalski P., 2006, Populacja osób bardzo starych w społeczeństwie polskim - stan obecny i perspektywy, [w:] J. T. Kowaleski (red.), Ludzie starzy w polskim społeczeństwie $w$ pierwszych dekadach XXI wieku (s. 115-150), Wydawnictwo Uniwersytetu Łódzkiego, Łódź.

Szukalski P., 2007, Przyczyny zgonów osób bardzo starych w Polsce, „Gerontologia Polska”, t. 15, nr 4, 97-103. 
Szukalski P., 2010, Skladowe zmian trwania życia wedlug grup wieku w Polsce $w$ latach 1950-2008, „Przegląd Epidemiologiczny”, t. 64, nr 3, 425-430.

Szukalski P., 2012, Solidarność pokoleń. Dylematy relacji międzypokoleniowych, Wydawnictwo Uniwersytetu Łódzkiego, Łódź.

Szukalski P., 2013a, Ludzie bardzo starzy we wspótczesnej Polsce, „Przegląd Socjologiczny”, t. 62, nr 2, 33-54.

Szukalski P., 2013b, Malżeństwo: początek i koniec, Wydawnictwo Uniwersytetu Łódzkiego, Łódź.

Szweda-Lewandowska Z., 2009, Popyt na miejsca $w$ domach pomocy społecznej wśród seniorów w Polsce w perspektywie 2035 roku, „Acta Universitatis Lodziensis. Folia Oeconomica”, t. 231, 243-254.

Vaupel J. W., 2010, Biodemography of human ageing, „Nature”, vol. 464, 536-542.

Walsh F., 2011, Families in later life: challenges, opportunities, and resilience, [w:] M. McGoldrick,

B. Carter, N. Garcia-Preto (eds.), The expanded family life cycle: Individual, family, and social perspectives (s. 261-277), $4^{\text {th }}$ ed., Allyn\&Bacon, Boston.

Wieczorowska-Tobis K., 2011, Specyfika pacjenta starszego, [w:] K. Wieczorowska-Tobis, T. Kostka, A. M. Borowicz (red.), Fizjoterapia w geriatrii (s. 18-27), Wydawnictwo Lekarskie PZWL, Warszawa.

Wolfer T.A., Runnion V.M, 2008, Dying, death, bereavement in social work practice. Decision cases for advanced practice, Columbia University Press, New York.

Wróblewska W., 2009, Teoria przejścia epidemiologicznego oraz fakty na przełomie wieków w Polsce, „Studia Demograficzne”, nr 1/155, 110-159.

\title{
THE OLDEST OLD IN POLAND - AN INVISIBLE TARGET GROUP FOR THE SOCIAL POLICY?
}

\begin{abstract}
The next decades will see a sharp increase in the number of the oldest old in Poland. The increase in the number of people aged 80 years and more will be caused both by the cohort factors, as well as by a decrease in the probability of dying at advanced and very advanced age. The paper is focused on the results of official population forecasts for the oldest old and on the related challenges that should be treated as important by social policy decision makers. Particular attention is paid to surviving to the age of eligibility for receiving long-term care services, changes in health status of the oldest old, factors affecting the range of family care, and to circumstances of death.
\end{abstract}

Keywords: The oldest old, social policy, social services for the elderly, demography of the advanced ages, Poland, 21st century 